\title{
Tourism and Employment: Opportunities and Challenges in Karnataka- Special Reference To Kodagu District
}

\author{
Dayananda.K.C, \\ Assistant Professor, Dept Of Economics, Govt First Grade College, Madikeri,Kodagu District, \\ Karnataka State,India
}

\begin{abstract}
Tourism is an industry capable of changing the socio-cultural, economic and environmental face of the world .Tourism is one of the largest and fast growing industries in the world. It has the potential to influence the living pattern of communities. It is one of the most important channels of cultural exchange which breaks down the barriers between people of different parts of the world. It is the collection of activities, services and industries that deliver a travel experience including transportation, accommodation, eating and drinking establishments of retail shops, entertainment, business and other hospitality services provided for individuals or groups of travelling away from home.

In developing countries like India tourism has become one of the major sectors of the economy, contributing to a large proportion of the National income and generating huge employment opportunities. It has become the fastest growing service industry in the country with great potentials for its further expansion and diversification. Tourism industry is capable to generate employment to both skilled and unskilled workers, directly and indirectly.
\end{abstract}

Key words: Tourism, Employment, Income, Opportunities, Location.

\section{Introduction}

Tourism is an industry capable of changing the socio-cultural, economic and environmental face of the world. Tourism is one of the largest and fast growing industries in the world, it has the potential to influence the living pattern of communities. It is one of the most important channels of cultural exchange which breaks down the barriers between people of different parts of the world. It is the collection of activities, services and industries that deliver a travel experience including transportation, accommodation, eating and drinking establishments of retail shops, entertainment, business and other hospitality services provided for individuals or groups of travelling away from home.

In developing countries like India tourism has become one of the major sectors of the economy, contributing to a large proportion of the National income and generating huge employment opportunities. It has become the fastest growing service industry in the country with great potentials for its further expansion and diversification.

\section{Conceptual understanding}

The word 'tour' is derived from the Latin word 'tornaro' and the Greek word 'tornos', meaning a 'lathe' or 'circle', the movement around a central point or axis. The Macmillan Dictionary defines tourism as "the business of providing services for people who are travelling for their holiday".

The World Tourism Organization define tourist as "people travelling to and staying in places outside their usual environment for not more than one consecutive year for leisure, business and other purpose". Tourism is a travel for recreational, leisure, business and education purposes. According to Webster dictionary tour means 'a journey at which one returned to the starting point a circular trip usually for business, pleasure or education during which various places are visited and for which usually planned".

\section{Home Stays}

Home stays are very important means to earn income and to generate employment in rural areas. Home stays is a form of tourism that allows the visitor to rent a room from local family to better learn and live. Home stays can occur in any destination of worldwide, some countries do more to encourage home stays than other as means of developing their tourism industry. Hosting a home stays allows the local family to earn some additional needed income. Home stay has linkage effect. It generates large scale employment opportunities in different ways. The advent of home stays boost up tourism in Kodagu. 
Home stays is a form of tourism that allows the visitor to rent a room a local family to learn the local lifestyle as well as to improve their language ability. While home stays can occur in any destination worldwide, some countries do more to encourage home stays than others as a means of developing their tourism industry. Hosting a home stay allows the local family to earn some additional, needed income. Home stay cannot be regarded as strictly commercial activity, but more of cross cultural exchange.

\section{Employment concept}

Employment is an important macroeconomic variable which explains both the Physiology and Anatomy of economic development. It is a means to achieve development and hence full employment is the goal of both the developed and developing economies. Employment is an opportunity to earn income, a means of self-respect and provides an entitlement and command over goods and services. Employment engages not only to people but also employs all other factors of production to produce goods and services.

\section{Quality employment}

ILO parameters of quality employment-

- Income level

- Condition of employment

- Absence of wage discrimination

- $\quad$ Status of employment.

\section{Decent Job}

In 1999 ILO has introduced the concept of decent work with the idea of restoring dignity to workers, in the background of decreasing quality of work Worldwide. The basic concept of decent work presumed productive work under condition of freedom, equity and dignity, where freedom would mean that the rights of the workers are protected, equity implied adequate remuneration for work and dignity would includes social coverage or protection. In the proposed study an attempt would made to examine whether theses quality of decent work prevails in the tourism employment.

\section{Theoretical foundation}

\section{Tourism Development Theories in a nutshell}

Multiplier effect - Tourism industry which is very much affected by the law of economics. For the last 40years economists dealing with tourism have developed a doctrine known as "Multiplier Effect" of tourism .The multiplier theory was enunciated in 1939 by Prof. Paul A Samuelson.

$\mathrm{K}=1 / \Delta \mathrm{C}$

K-Multiplier

$\Delta \mathrm{C}$ - Change in consumption.

$\Delta \mathrm{Y}$ - Change in income.

According to this theory the multiplier ' $\mathrm{K}$ ' is dependent on the relationship between a change in consumption ' $C$ ' and change in income ' $\mathrm{Y}$ '. The theory can also be applied to tourism. When a tourist visits a place and spends his money in that particular region, parts of this money become income for the people living in that region. A part of this income again spent and so on and so forth. Thus money changes hands a number of times and is spent and respent. The impact of this expenditure in nation's economy will be on multiplying.

Butler Theory (1980)-Butler theory is based on business marketing concepts of the product life cycle. Butler suggests that resorts or destinations develop and change over time according to linked stages. According to this theory the initial stage of tourism area cycle is considered as exploration stage. In this stage tourists start to come to destination and they are attracted by natural features. There is maximum contact between tourist and community. Second stage is the involvement stage. In this stage more tourist start to visit the destination and local people become involved in providing services to tourist and develop a necessary infrastructure. In the next stage is development stage. At this stage the tourist market becomes defined and tourist season starts to develop. Fourth stage is consolidation stage, here tourism continues to increase but the rate of increase declines. Final stage is stagnation stage at this stage tourism reaches its full capacity.

Irritation index theory (1975) - was developed by Doxey and was known as an Irridex Doxey's theory is built upon the premise that any destination will be developed and grows over a period of time as the number of tourist increase and then hostility from locals would emerge towards tourist. Doxey suggest that over time local residents become more hostile to tourist. This theory considers the relationship between tourist and residents of tourist destination and it also gives us an understanding of tourism impact and tourism development 
Plog theory on psychology of tourist (1973) - Plog developed theory on psychology of tourist. Plog's important contribution was the notion of types of tourists. According to him there are psychological types of tourists who do not like unfamiliar environments or cultures. So when they plan for a holiday they will seek familiar places. The other group of tourists like adventure and prepare to risk for more uncertain holding destination.

Cohen's theory of tourism (1972) - Cohen developed a typology of tourists in which he classified the tourist as organized mass tourists, individual mass tourist, explores and drifters. Cohen revealed that relatively few tourists would come into contact with more distant and different cultures and tourism destination would be developed relatively close to tourism generating regions.

\section{Employment Theories in a nutshell}

The best way of understanding the determinants of employment growth and the nature of state intervention in stimulating employment generation is to review the major employment theories which are as follows.

The classical Model assumes full employment and believed that Laissez faire and free play of the market forces, along with price wage flexibility ensures full employment.

J.M.Keynes criticizing classical approach, through macro economic theory of Income and Employment asserted that underemployment is a normal feature, role of Government in pumping the purchasing power is essential and wage are rigid downwards but flexible upwards.

Harrod - Domar Model, an extension of Keynesian model, argues that investments both autonomous and induced are important determinants of employment growth.

The supply side Economists argued that the fiscal, especially tax policy, influences significantly the growth of employment. growth.

The RATEX Model identifies the future expectation, risks and uncertainties determine employment

The Price incentive model reveals that technology is a major determinant of employment growth. Similarly the Harris -Todaro Model explains that Rural -Urban migration determines the nature of employment growth. In this theoretical background the proposed work aims at capturing the role of tourism development in creating employment opportunities.

\section{Tourism in India}

The first conscious and organized initiative to promote tourism in India was undertaken in 1945, when a committee was formed by Govt. under the chairmanship of Sir John Sergent, the then educational advisor to the govt. of India. Therefore, the tourism in India was accorded a privileged place in 1956 with the formulation of $2^{\text {nd }}$ and $3^{\text {rd }}$ five year plan. The $6^{\text {th }}$ plan marked the beginning of new era when tourism began to be considered a major instrument for social integration and economic development.

After 1980 that tourism activity gained monument. Government took several significant steps to develop tourism sector. A national policy on tourism was announced in 1982. Later 1988 the National committee on tourism formulated a comprehensive plan for achieving sustainable growth in tourism. In 1992 a National action plan was prepared and in 1996 the National strategy for promotion of tourism was drafted. In 1997 the new tourism policy recognizes the role of central and state government, public and the private sector in development of tourism and also the need for involvement of Panchayath Raj institution, local bodies, nongovernmental organizations(NGOs) and the local youth in the creation of tourism facilities has also been recognized.

\section{Present scenario of Indian tourism}

Tourism has become a popular Global Leisure activity. After 1990s tourism sector has been boost up all over the World. The General Agreement on trade in services (GATS) is the first Multilateral trade agreement it covers trade in services. Its creation was one of the major achievements of the Uruguay round trade negotiation from 1980 to 1993.

General Agreement on Trade in Services (GATS) is a treaty of World Trade Organization (WTO) that entered into force in January, 1995 as a result of Uruguay Round of Negotiation. The treaty was created to extend the Multilateral Trading system to service sector. Main Goal of GATS is to remove barriers of trade in 
services and members are free to choose which sectors are to be progressively liberalized, market zed and privatized. Trade in services refers to the sale and delivery of intangible product. Today tourism is the largest service industry in India, with a contribution of $6.23 \%$ to the National GDP and providing $8.78 \%$ of the total employment. India witnesses more than 5 million foreign tourist arrivals and 562 million domestic tourism visits. Tourism industry in India generated about US $\$ 100$ billion in 2008 and that is expected to increase to US $\$ 275.5$ billion by 2018 at a $9.4 \%$ annual growth rate. Tourism sector is very important service sector which is growing very fast after 1990s.In 2011 there were over 983 million international tourist arrivals worldwide representing a growth of $4.6 \%$ when compared to 940 million 2011

\section{Tourism in Karnataka: An overview}

Karnataka is situated in the Southern part of India, and province of Karnataka spreads over the Deccan plateau. Karnataka is the largest state in India in both area and population. It was formerly known as Mysore. On November 1, 1973, the name Mysore was changed to Karnataka. The name of the land Karnataka has come from 'Kari-nadu', meaning the land of black soil say the scholars and some others hold that 'Karunadu' also mean beautiful country'. The state of Karnataka situated between $74^{\circ} \mathrm{E}$ and $78^{\circ} \mathrm{E}$ longitudes and between $11^{\circ} \mathrm{N}$ and $18^{\circ} \mathrm{N}$ latitudes.

The topography of Karnataka is largely a reflection of the geology of the State. The sahyadris are covered with evergreen forests. They drop abruptly towards the Arabia Sea, thus forming a natural barrier between the plateau and the coastal region. Four passes provide access to the coast. They are SubramanyaGhat, CharmadiGhat, ShiradiGhat, and famous AgumbeGhat. The Western Ghats slope gently towards the Bay of Bengal. This is the plateau region drained by the two principal rivers Krishna and Kaveri. The average elevation of the plateau is about 610 meters above sea level.

Karnataka is manifold attraction includes everything that interests the visitors. The wild life sanctuaries at Bandipur, Nagarahole and Dandelli, the Ranganatittu Bird's sanctuary $5 \mathrm{~km}$ from Srirangapatna which is itself a well known tourist center., hill stations like Nandi hills and Kemmannagundi and Mercara, Beach resorts like Karwar, Ullal, Malpe, Maravanthe, the world famous Brindavana Garden at Krishnarajasagara, Monolithis statue of Gommateshwara at Shravanabelagoala, GolGumbaz with its whispering gallery at Bijapur, the Jog falls and other waterfalls at ShivanaSamudra, Magod,Unchelli, Halguli at Yallapur, Abbi falls at Madikeri and other places indicates the variety and richness of the attraction at Karnataka state holds out the visitors. There are many places of historic and religious importance which are also attracting lot of tourists. The great Acharyas, Shankara, Ramanuja and Madawa preached in this region. Great reformers like Sri Basaveshwara, Mathematicians like Baskaracharya, Saint Poets like Purandaradasa and Kanakadasa, great writers like Pampa, Harihara and Kumaravyas have all enriched the heritage of Karnataka.

\section{Kodagu Tourism Profile}

Kodagu is one of the most beautiful hill stations .Proudly nicknamed as "Kashmir of south "and "Switzerland of India". Blessed with beauty and bounty of forest and mountains, it is truly a nature lover's paradise with great landscape, lush green valleys, misty woods, Racing River and enchanting waterfalls. Kodagu is a smallest but most picturesque district of Karnataka state in south India.Kodagu the thickly wooded grandrure on Weastren Ghats is the most beautiful hill station of Karnataka.Kodagu civilization has a 2500 year old history.

Kodagu is situated at $4000 \mathrm{Ft}$ above the sea level and full of dense forests, mountains, range of rivers and paddy fields. It has an area of 4102.3 SqK.M.with approximate 6 lakhs population. Madikeri is the head quarter of kodaguand is $252 \mathrm{Kms}$ from Bangalore and $120 \mathrm{KM}$ from Mysore. It has average annual rainfall of 2700 .m.m, 32.37\% of geographical area comprise of forest. Protected areas are Rajivagandhi National Park(643Sq.Km), Talakaveri Wildlife Sanctuary (105 sq Km),Pushpagiri Wildlife sanctuary (102.59sq km), Brahamagiri Wildlife sanctuary $(181.29 \mathrm{sq} \mathrm{km})$. The district has several amazing mountain, trekking points namely Thadiyandamole(highest peak with 5820 (ft),Brahamagiri (5500 ft),pushpagiri(5400ft),Kotebetta (5369ft), Iguthappa (5521 ft),Mandalapatti (2200ft), Nishanmotte (4396 ft), Thugapare (4400 ft), Chomakundu, Gaddigesiddeshwara etc. Kodagu has wonderful waterfalls like Abbey falls, Surlabi falls, jodupala falls, Barapole falls, Irpu falls, Kumaradhara falls, Chelvara falls, Mokkodlu falls, Kallalli falls etc. Various other tourism spots are Nisargadama, Harangi dam, Chiklihole dam, Dubare Elephant camp, Stone hill, Hattihole river, Honnammanakere, BhagamandalashreeBhagandeswara temple, MadikeriOmkareswara temple, PadiIgguthappa temple etc.

Approximate tourist inflow per annum is 500000 people. Kodagu has very close relationship with United Kingdom. Many people of Kodagu settled in U.K. Therefore every year more number of English people come and spends their time. Agriculture is the main occupation and source of income. The recent growth of 
tourism in the district has positive impact on the employment, business, income and standard of living of the local people. One of the recent developments in tourism of Kodagu is mushrooming up of home stays, which will provide the royal treatment to the tourist, with the delicacies of traditional foods.

Kodagu a hedonist's paradise by all means with hills, old-world charm, coffee, amazing food, vivid cultures and warm hospitality. There is something in the air in Kodagu that makes all things beautiful. Its people are fair. Its hills, scenic and unforgettable.Its food, wholesome and tantalizing.Its pools, pristine and clear.Its cultures vibrant and exclusive.Kodagu is an aristocrat, through and through. The stronghold of the Gowda and Kodava community, who are belived to be descendants of the Aryans.Coorg keeps its traditions, and as warm as your reception might be, you are reminded constantly that you are a guest and certain decorum is expected out of you.Madikeri is a cornucopia of times past. The green ,hilly capital of the Kodagu region has remnants of its past like the Madikeri fort ,raja's seat. Where you can catch a sunset just like the raja's once did acres of coffee estates and the Raja's tomb where the Kodagu king Veererejendra and his family sleep their eternal sleep. About $9 \mathrm{~km}$ away from Madikeri's giddy heights are the Abbey Falls, which falls daintily in steps, looking like a pretty curtain of the finest lace.TheTalacauvery where the Cauvery originates. Bylekuppe about 40km away from Madikeri opens doors to an entirely different world. The Buddhist colony here is a piece of Tibet in itself.

\section{Statement of the problem}

History reveals the harsh realities of travel in ancient times and civilization in search of basic necessities of life such as water, food, shelter and safety. In the absence of organized roads, people travelled by foot or on animal backs over open fields, forest etc. Civilization, Modernization, industrlisation which promotes tour and travel across the world. Now tour is order of the day and also fashion of human life. The development of tourism in India is fascinating subject. India's glorious tradition and rich culture heritage are closely linked with the development of tourism. India in recent years has gained good exponential growth in the tourism industry. Today India is the preferred destination for both overseas and domestic travelers. Tremendous growth in the Indian economy is the main reason for the growth in tourism in India.

Karnataka is $9^{\text {th }}$ largest state in India in terms of population as per as 2011 census. "As the result of high population unemployment rate is also very high. Tourism sector is one which gives large scale employment opportunity and reduce the problem of unemployment some extent. Karnataka is fast growing economy,although there are number of people are illiterate, they do not get job opportunities. But tourism industry provides employment opportunities not only educated but also uneducated or illiterates. In Karnataka state many people do not get basic needs because of the problem of poverty. Poverty is due to lack of source to earn income. But tourism industry it gives opportunity to earn income both educated or skilled and unskilled labours, as the result poverty rate declines.

Karnataka has very good number of tourist spots. It has number of tourism sites or locations, both national and manmade as artificial. It attracts more number of people across the world. There are number of tourist destination not yet developed. When govt. gives support or incentives definitely that spots will develop and automatically social and economic infrastructure facilities will expand. Tourism industry has chain linkage, with all other sectors like bank and insurances, trade, transportation, communication, education etc., Therefore overall economic development will take place. Karnataka has good coastal and airline as well as international airport and sea port; it attracts more number of foreign tourists and helps to Karnataka state to earn more foreign exchange, cultural exchange.

Recently Karnataka state government invited foreign investors, MNCs to invest in this tourism sector. As the result of foreign investment tourist people may get good and qualitative services and economy will develop. In Karnataka there are number of unexplored tourist spots were explored since 2005. Home stays are mushrooming up in Karnataka especially in Kodagu district and numbers of tourist spots were explored.

\section{Review of Literature on Tourism Development and Employment Growth}

A literature review is a body of text that aims to review the critical points of current knowledge including substantive findings as well as theoretical and methodological contributions to a particular topic. Literature reviews are secondary sources and as such, do not report any new or original experimental work. Also, a literature review can be interpreted as a review of an abstract accomplishment. The literature review starts with the selection of a problem for research, continues through the various stages of the research process and ends with report writing. In this research work review of literature is classified as follows:

1. Literature Review at Global Level.

2. Literature Review at National level.

3. Literature Review at State level. 


\section{Literature Review at Global Level}

Aguayo Eva (2011) in his paper 'Impact of Tourism on Employment: An Econometric Model of 50 Central and East European regions' analyzed the economic impact of tourism development. He employed an econometric model to show that there is positive impact of tourism on employment and market services. In this paper the model shows the positive impact of tourism on the services sector. Tourism could be faster both in employment growth and regional development through the sectoral linkages within the region.

Bhatia A.K. (2010) in his book 'Tourism Development Principles and Practices'

Gives complete picture of historical dimension of tourism and its economic significance. Tourism income multiplies infrastructure, regional development, employment multiplier etc. This book also gives complete information relating to various organizations of tourism and role of travel agents in tourism development.

ILO Global Dialogue Forum on New Developments and Challenge (2010) reveals that the travel and tourism industry is the largest and most dynamic industry. Global economy is expected to generate about $9 \%$ of total GDP and provides more than 235 million jobs in 2010 representing 8\% of Global employment. According to ILO report prepared for the Forum International Tourism was affected by the global economic and social crisis and expecting the tourism sections global economy to provide 296 million jobs by 2019. Tourism has the potential to become a major generator of job.

Fifth UN-WTO International conference (2009) on Tourism Statistics at Bali, Indonesia, considered Tourism as an engine for employment generation. The Conference report states that the rate of growth of employment opportunities for youth and women is the highest in service sector, especially tourism. However seasonal fluctuations in tourism destinations create situation of irregular use of potential workforce, causing seasonal unemployment. In fact this creates an additional burden on unemployment insurances.

Ajala.O.A. (2008) in his work on "Employment and Income Potentiality of Tourism Development in Amhara region Ethiopia" examined the role of tourism development in socio-economic development of the region, generating foreign exchange, reducing unemployment and in improving the living standard of the people. The author has focused on Hotel industry, Souvenir, Tour guide, and water transport business.

Jagmohan Negi (2008) in his book "International tourism and travel, concept and principles" discussed about scope and composition of tourism and travel, types and characteristics of Tourism, tourism marketing policy, job structures in travel trade, tourist accommodation and tourism transportation facilities etc.

Stephen J page, Joanne Connell (2006) in his book "Tourism A Modern Synthesis" identified the potential of tourism industry in Employment generation and examined the various determinants of employment creation in tourism, particularly the types of tourism .Resort Development will create variety of new jobs but may not always benefit more the local people.

Kim et al study (2006) examines the casual relationship between tourism expansion and economic development. This study reveals that tourism expansion and economic development have a reciprocal relationship in Taiwan.

Mckercher et al studies (2005) have conducted a study to examine the nature of relationship between tourism and cultural heritage management in Hongkong. The result of this study shows the positive relationship between tourism and cultural heritage management.

Lim and McAleer study (2005) critically examined the management practice, problems and challenges faced by two ecotourism attractions located in the Gold Coast and Brisbane in Queensland, Australia. The study focused on two case studies of best practices of ecotourism management and pro active Sustainable tourism stance of an eco resort and wetland reserve and concludes that sustainable tourism could make significant contribution to the quality of environment, economic development and well being experience for the visitors and tourists. The study shows that both resorts have demonstrated a commitment to environment of the communities apart from generating lot many employment opportunities.

Tosun (2001) has conducted a study on "Challenges of Sustainability of Tourism Development in Developing World". This study reveals that in developing world governments do not have many alternatives other than supporting current tourism development even though it may not be compatible with the principles of long term 
sustainable development. The tourism development models meant for developed countries do not necessarily meet the needs of the developing nation.

\section{Literature Review at all India Level}

Lalnumawia(2012) in his article "Development and Impact of Tourism Industry in India" in this article analyzed the impact of tourism industry on development, the process of development of tourism, present situation and features of tourism in India. This article examined constraints of tourism development in India and analyzed several positive and negative impact of tourism on economy and society

Sandeep Das (2011) in his paper "Tourism Contribution towards Employment Generation" analyzed that tourism industry has lot of potentiality in generating employment opportunities, forced earning to achieve higher economic growth.In the $11^{\text {th }}$ five year plan period number of programmes, incentives have beentaken by the Govt. to develop tourism industry under Incredible India Revolution scheme.

Dives Chathurvedi (2010) in his work 'Tourism in India- A bird view' analyzed that tourism is the largest sector in terms of generating employment. It helps to maintain balance between demand for and supply of human capital.IN other words, tourism industry has tremendous potential for employment generation.

ManjulaChowdari (2010) in her paper "Tourism: Human Resources Development" analyzed that tourism is very important force for the development and it is mainly labour intensive industry. Tourism sector provides large scale employment, especially for women, youths, minorities etc., She identified some obstacles to tourism sector such as scarcity of expertise, technological backwardness, challenges in employment diversification etc.

Vijay Takoor's (2010) article 'Rural Tourism' examines that rural area, due to lack of shelter, infrastructure facilities and so on could not attract more number of tourist people. Rural tourism market facilitates for the development of art, culture, artisans etc.Rural Tourism begain in India since 2002, with the main objective of exposing cultural richness to world.

Srivastava (2010) in his paper "Ecotourism Means for Community Development" examined that tourism is not only complementary for the economic development but also it improves quality of internal environment, goods, transport, hotel etc., it also provides largest employment opportunity to youths and also encourage cultural development. Tourism industry helps to maintain good relationship between host and home countries citizens.

Nafees A Khan (2008) in his work on "Human Resource Development in Tourism Industry in India A Case Study of Air India Ltd" made an attempt to analyze the HRD initiatives of tourism industry with special reference to Air India Ltd., to enhance and sharpen the capabilities of its employees. The study also identifies the need of the Air India to incorporate the spirit of HRD in day-to-day functioning. He identified the role of HR Manager in selecting and recruiting the right kind of people, who can be an asset for the tourism sector.

ChandrakantaSahoo's (2008), article on "Insight into Indian Tourism Sector" observed that Indian tourism is a potential source of employment which will help in sustainable development of the country. India exploits around $0.6 \%$ from the world tourism sector which contribute around $6.23 \%$ to the country's GDP presently. Tourism sector in India not only adds to country's GDP but also has the potentiality to generate employment to a large extent. Its growth automatically can be moved towards a sustainable development. In tourism sector there were $207 \%$ million people employed is world while in India 25 million and India is the second largest employment generator in the field of tourism.

Tourism finance corporation of India Ltd. (2007), in its Report on 'Evaluation of the Schemes Incentives to Accommodation Infrastructure in India', reveals that Ministry of Tourism, Govt. of India introduced a scheme of capital investment subsidy in the year 2002, which was available during the $10^{\text {th }}$ Plan period till 2007, for setting up hotels in 1, 2, 3 star category and heritage hotels with an objective to increase the supply of hotel in the budget category in the country. The Report found that the financial incentives play a partial role only in the augmentation,compared the other issues related to overall tourism developments, land prices, availability of good location, taxation etc.

JesimPais's (2006), paper on ' Tourism Employment An Analysis of Foreign Tourism in India' reveals that foreign tourism is one of the largest industries in the world today. While foreign tourism has been growing steadily in India, it still has large unexploited potential for future growth. Tourism growth generates 
employment at all skill levels. The paper attempts to estimate total direct employment generated in India by the fact tourism is a composite sector. This paper uses a simple and innovative method of employment co-efficient to arrive at estimates of employment generates of foreign tourism in India. The employment co-efficient are computed for such sectors and sub sector that provide goods and services to foreign tourist as hotels, restaurants, transport and travel services. Cultural and recreational services trade and manufacture.

Yashodhara Jain (1998) in her book 'Development of Tourism in India' examines the determinants of the growth of tourism industry like science and technology, economic abundance and revolutionary change in the field of transport and communication.

\section{Literature Review at State Level}

Uma.H.R' s (2010) work on 'Tourism in Karnataka Home stay concept' reveals that tourism industry attracts more number of tourist people to Karnataka from across the world and Karnataka consist of $50 \%$ protected monuments. Decline in coffee production since 1990s in Kodagu district, has led to tourism industry development particularly Home stays. Coffee estate owners used their big, beautiful bungalows, vehicles, estate for the tourist purpose. Home stays especially created more jobs for women and empowered them.

Revised Master Plan for Development of Tourism in Karnataka (1997) published by Dept of Tourism, Govt. of Karnataka has identified 5 circuits-Northern, Southern, Coastal, Wildlife and hill station circuits.In the development of tourism private public partnership is recommende for the promotion of tourism in the State. The revised master plan envisages the improvement of infrastructure facilities in these circuits with the help of private Sector.

\section{Research Gap}

The literature review reveals that there is scope for examining the relationship between tourism development and employment growth at the micro level. Further since GATT agreement in 2005 trade in services has led to a tremendous increase in employment opportunities and this has called for an empirical investigation in the employment potential of tourism industry. However the nature and quality of employment differs significantly from that of organized sector. But in India both national and regional levels there are very few studies particularly since GATT. The impact of tourism industry on employment linkage, quality or nature of jobs and particularly role of home stays in employment generation etc are explored. In the background of declining employment elasticity in the organized sector any study that is related to employment potential in various economic activities deserve lot of empirical value addition .Moreover, in Karnataka, tourism industry is flourishing, more so in Kodagu district. The expansion of tourism activities is very significant due to various reasons already mentioned. Further there are 1200 home stays in Kodagu district alone. Hence the present study proposes to capture the employment potential in home stays in Kodagu district, which is directly linked with the expansion of tourism industry in Kodagu.

\section{Methodology and data collection}

The present study is based on both secondary and primary data. Primary sources are personal interview method, field survey, scheduled questionnaires etc. Various secondary sources are data consists Annual report of Karnataka State Tourism Department, Information and Broad casting department, Kodagu district Statistical Department, Kannada and Cultural Department, International Tourism Agency, internet, news papers, magazines, books, broachers, articles and thesis etc. To test hypotheses various scientific tools, statistical and mathematical tools and techniques will be employed .This research work is mainly concerned with tourism development and employment growth in Kodagu district since 2001-12 period.

Kodagu district has three taluks namely Madikeri, Somwarpet and Virjpet each taluks has good number of tourist spots which attracts more number of tourists from domestic as well as foreign.Primary study is mainly based on sample survey. Samples are collected equally form each taluks.

\section{OBJECTIVES OF THE STUDY}

The main objectives of the study are as follows:-

1. To Study the Tourism Development Policy of the State.

2. To examine causality between Tourism Development and Economic Growth in Karnataka and Kodagu District.

3. To examine the relationship between Tourism Development and Employment Growth in Karnataka and Kodagu District.

4. To study the factors determining the Growth of Tourism in Kodagu District.

5. To study the nature and quality of Employment in Tourism Sector in Kodagu District especially in home stays. 


\section{Hypotheses of the study}

1. There is positive correlation between tourism development and economic growth.

2. Growth of tourism and employment are positively related.

3. Risk and uncertainties characterize jobs in tourism industry.

4. Growth of Tourism and expansion of infrastructure are positively related.

\section{Scope and importance of the Study}

India gained good exponential growth in the tourism industry in recent years. Today India is the preferred destination for both overseas and domestic travelers. Tremendous growth of the Indian economy is the main reason for the growth in tourism in India. Tourism industry in India is substantial and vibrant. It is most profitable sector in India. In during 2006, four million tourists visited India and have spent US \$8.9 Million. In India the disposable income has gone up by $10.11 \%$ annually from 2001-2006, when much of that is being spent on travel. Indian tourism industry is ranked $11^{\text {th }}$ in the Asia Pacific region and $62^{\text {nd }}$ on the list of the world attractive destinations. As per the Travel and Tourism Competitiveness Report 2009, by the World Economic Forum, India had been ranked $14^{\text {th }}$ for the best tourist destination and for its natural resources and $24^{\text {th }}$ for its cultural resources, as it has most of the world heritage sites, both natural and cultural, rich fauna and flora and strong creative industries in the country. Indian tourist industry is ranked $5^{\text {th }}$ in the long term growth and is expected to be the second largest employer in the world by 2019.Indian tourism is the largest services industry with a contribution of $6.23 \%$ to the country's GDP and $8.78 \%$ of total employment of the Nation.

Karnataka is in the south west of India is a prominent tourism hub, attracting tourist from across the world. Karnataka tourism has a seen a boost owing with capital, Bangalore emerging as the IT centre of the country. The flourish in the tourism has triggered the mushrooming of the resorts and home stays across the state facilitating better travel experience. Karnataka has good numbers of Pilgrimage, Temples, Beaches, Adventures, Hill stations, Wildlife and National Parks, Waterfalls, Heritages etc. In Karnataka tourism has very wide scope which provides very large employment

Kodagu is one of the most beautiful hill stations proudly nicknamed as 'Kashmir of south'. Blessed with beauty of forest and mountains. Approximate tourist inflow per annum is 500000 people. One of the recent developments in tourism of Kodagu is mushrooming up of home stays, which will provide the royal treatment to the tourist. Growth of tourism industry in Kodagu has good linkages with other sectors and provides employment directly as well as indirectly and improves income and standard of living of the people.

The dynamics of employment growth since 1990s have clearly revealed that the organized sector has little scope for increasing employment elasticity and has substantially contributed to "jobless growth". Therefore society or state has to look towards other economic activities which are more labour intensive in nature. In this context, tourism development has been identified as one of the most significant activities which can stimulate the diversified growth of employment through various supply chain activities. The GATS agreement in 2005 has created tremendous opportunities for trade in services, particularly in tourism sector. Besides the state intervention under neo-liberal system has been exploring new avenues for employment generation. Kodagu district in Karnataka, being the most favored destination of tourism, is attracting the attention of both tourists as well as the state. An up surge in medical tourism has a significant impact on tourism employment. In this background the present study intends to explore the new dimension of employment policy with the expansion of tourism activities.

\section{Rationale for selecting Kodagu District for Case Study}

Kodagu is very attractive place and attracts tourists from all over the world. Tourism is one of the very important means to livelihood in Kodagu district. Many spots which have been left unexplored in the past are being explored for the purpose of tourism. Kodagu is a very beautiful place for tourists and attracts thousands of foreign and domestic people every year. Kodagu is very famous for Orange and honey and very small district in terms of geography. Agriculture is the main back bone of Kodagu economy. Since 1990s onwards, tourism sector has been flourishing in Kodagu. Water sports, Golf, elephant camp, Cattle camp(Mela), historical spots, palaces, rich culture, tradition, beautiful landscapes with river, mountains, lush greenery, estate, luxurious and reputed hotels like Taj, Club Mahindra, Orange county etc, food habit, hospitality of Kodagu people are main causes for flourishing of tourism in Kodagu district.

The advent of home stays in Kodagu has boosted up tourism. Since 2010 home stays are growing very rapidly in Kodagu. At present more than 1200 home stays are there in Kodagu. Home stays are both organized and unorganized. Unorganized home stays out number organized home stays. Both organized and unorganized home stays generate more job opportunities for both skilled and unskilled workers and also through various linkage effects. 


\section{Employment Opportunities in Tourism industry in Kodagu District}

I. Restaurants: Due to the development of tourism in Kodagu , number of restaurants are increasing day by day. Thus providing various job opportunities for unemployees. Day by day the income of the restaurants is increasing, thus increasing the wages of the workers working there. From the trained people, like manager even the untrained sweepers, cook and others getting good wages.

II. Home stays: Home stays are very important means to earn income and to generate employment in rural areas. Home stay is a form of tourism that allows the visitor to rent a room from local family to better learn and live .Home stays can occur in any destination of worldwide; some countries do more to encourage home stays than other as means of developing their tourism industry. Hosting a home stays allows the local family to earn some additional needed income. Home stay has linkage effect. It generates large scale employment opportunities in different ways. The advent of home stays boost up tourism in Kodagu.

III. Lodges:The rapid growth of lodges is also the result of tourism growth. It has created several job opportunities even for the illiterates. The lodges which were almost vacant with dust are now found to be always full of tourists because of the tourism growth

IV. Transportation: Taxies are in great demand as the tourist always want taxies as means of transportation. The taxi owners and drivers are paid whatever money they demand from the tourists. This has also created several job opportunities.

V. Coffee days: This concept is also introduced to villages now. Home- makers especially at villages a now making good fortune by their dhesi style coffee cafe days.

VI. Shopkeepers and street traders :The number of shops and street traders are increasing, thus providing job opportunities for untrained and unskilled.

VII. Enchanting waterfalls: Kodagu has wonderful waterfalls like Abbey,Surlabi, Jodupala, Barapole, Irpu,Kumaradhara,Chelavara,Mukkodlu,Chettalli falls and many others make the tourists feel heaven on earth.

VIII. Reservoirs: Harangidam,Chikliholedam,Honnamanakere,KaveryNisargadhama etc welcomes tourists in large numbers.

IX. Resorts and Restaurants:World famous resorts and restaurants namely Taj,Mahendra, Heritage, Thamara,Orange county etc situated in lush greenery attracts tourists.

X. Suitable weather condition: Kodagu proudly nicknamed as "Kashmir of South" and "Switzerland of India" welcomes the tourists with pleasant breeze . The cool weather conditions enables the tourists to enjoy the beauty of Kodagu.

XI. Homestays:One the recent developments in tourism of Kodagu is mushrooming up of homestays, which provides royal treatment to the guests.Foodhabits,hospitality of people of Kodagu are the main reasons for flourishing tourism in Kodagu district.

XII. Sports activities:Thefamous Gowda and Kodava cricket and hockey family tournaments reflects the healthy relationship and brotherhoodness of people of Kodagu.These matches also attract people from far away places.

XIII. Food habits:Thetraditional food habits followed in Kodagu plays a vital role in tourism development.Theakkirottis ,pork curry,,riceballs,pathrode,atypaysam,thambittu and many more mouth watering food items attracts tourists.

\section{Challenges of tourism in Kodagu district:}

1. Pollution:Kodagu, once known as pollution free district is now getting polluted to the maximum due to the growth of tourism.

2. Density of population and vehicle: Increase in the density of population and vehicles have disturbed the calmness and healthy living of the people.

3. Deforestation: With the growth of tourism ,money making has landed firmly in the people. Home stays have substituted the place of forests. Green land is slowly been converted to dry land.

4. Shortage of rented houses: There is shortage of rented houses due to the development of home stays .The rents have also reached its peak value and the middle man is struggling to survive being unable to pay the rent.

5. Lop sided development: With the development of tourism sector , only tourism spots are developed ,whereas other regions are lagged behind the main stream of economic growth.

6. Increase in crime rate: With the growth of tourism the increase of theft and other illegal activities are also increasing.

7. Naxalism and Terrorism: Proper details of a person is not demanded in home stays, as their main intension is only money making. As a result it leads to various terrorist activities . 
8. Expensive livelihood: The rates of each and every commodity are increasing as the demand for the goods is also increasing. This has made common man to struggle for life.

9. Loss of valuable Culture: Tourism leads to demonstration effect, as a result youths are completely westernizing themselves adopting western culture and neglecting our precious cultural.

10. Lack of interest in agriculture sector:As tourism growth is providing job opportunities even to the untrained, agriculture is completely neglected and the agricultural lands are converted into home stays , resorts commercial sites etc.

\section{Conclusion}

Kodagu the most beautiful place, blessed with beauty and bounty of forest and mountains, is truly a nature lovers's paradise with great landscape, lush green valleys, mistywoods, racing river and enchanting waterfalls. Kodagu has great opportunities for tourism development, thus creating large scale employment opportunities, generating income, improving standard of living and contributing for economic development of the nation. All these developments truly depends on the people of Kodagu, as they have a great responsibility of overcoming the challenges and marching towards sustainable development.

\section{References}

[1]. Aguayo Eva (2011). "Impact of Tourism on Employment: An Econometric Model of 50 CEEB Regions", Vol.11-1, pp37-46.

[2]. Bhatia A.K. (2010), "Tourism Development Principles and Practice".

[3]. ILO Global Dialogue forum (2010) "New developments and challenge in the hospitality and tourism sector"

[4]. Fifth UN-WTO International conference (2009), "Tourism an engine for employment creation", Bali, Indonesia.

[5]. Abdul MalekHamoud (2009), "Tourism development in Aden, republic of Yemen a study of the impact of tourism and local community".

[6]. Ajala.O.A.(2008), "Employment and income potentiality of tourism development in Amhara region Ethiopia".

[7]. Stephen J page, Joanne Connell (2006), "Tourism a modern synthesis, Thomson publication".

[8]. Krishna K Kamra, Mohinder Chand (2004), "Basic of tourism theory, operation and practice".

[9]. Tosun (2001), "Study on challenges of sustainability of tourism development in developing world".

[10]. Calvin Jones and Max Munday (2001), "Tourism and local economic development: Three case studies".

[11]. David little john (2001), "Business travel markets: New paradigms new information need".

[12]. Lalnumawia(2012), "Development and impact of tourism industry in India".

[13]. Sandeep Das (2011), Tourism contribution towards employment generation.

[14]. Dives Chathurvedi (2010), Tourism in India, A bird view.

[15]. ManjulaChowdari (2010), Tourism: Human resources development.

[16]. Vijay Takoor (2010), Rural tourism.

[17]. Srivastava (2010), Ecotourism means for community development.

[18]. Nafees A Khan (2008), Human Resource Development in Tourism Industry in India, a case study of Air India Ltd.

[19]. ChandrakantaSahoo (2008), An insight into Indian tourism sector

[20]. Tourism finance corporation of India Ltd. (2007), Final Report on Evaluation of the schemes, Incentives to accommodation infrastructure in India.

[21]. JesimPais (2006), Tourism employment as analysis of foreign tourism in India.

[22]. J.K.Sharma(2006),Tourism Planning and Development, A new perspective Kanishka Publication, New Delhi .

[23]. Yashodhara Jain (1998), Development of tourism in India.

[24]. Sinha P.C. (1998), Geography of tourism and Models in tourism.

[25]. Shalini Singh (1994), cultural tourism and heritage management.

[26]. Vijayakumar Gupta (1987), Brief Guidance of tourism in India.

[27]. Uma. H.M. (2010), Tourism in Karnataka Home stay concept.

[28]. Chowdaiah (2002), Growth of tourism in and around Mysore city, a geographical analysis.

[29]. Revised master plan for development of tourism in Karnataka (1997).

[30]. Rao, V.S.P. (2004), Human Resource management, Excell Books, New Delhi.

[31]. Report (2004-5), Ministry of tourism, Govt of India, New Delhi.

[32]. PTI Report (1999), The times of India, New Delhi.

[33]. Economic Survey (2010-11), Ministry of Finance, Govt of India, New Delhi.

[34]. WTO (2001), Tourism Satellite account.

[35]. WTTC (2004) India travel and tourism forging Ahead, the world travel tourism council, London.

[36]. www.Indiatourism.com

[37]. www.travelindia.com 